\section{Eco de un ave que estalla: del Twitter al papel}

\section{Lizarlett Flores-Díaz}

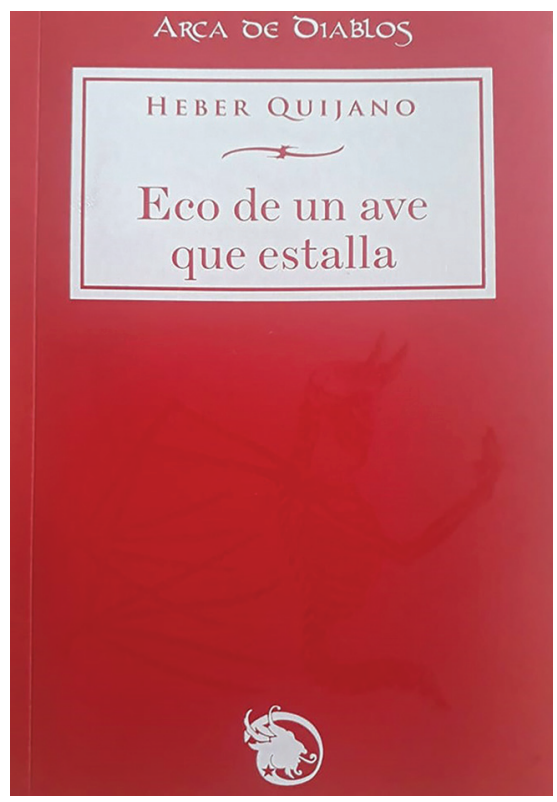

Heber Sidney Quijano, Eco de un ave que estalla, Toluca, Diablura Ediciones, 2020, $76 \mathrm{pp}$. os lectores tenemos mala memoria. Cerramos páginas, cambiamos de libro y olvidamos. En los últimos años podemos justificar este descuido como una herramienta de selección debido a la información rebosante de nuestras pantallas. En medio de dicho torrente, algunas veces aparecen textos que nos cautivan por su estructura y contenido, y cuyo sentido continuamos paladeando mucho tiempo después de haberlo leído, aunque el raudal de noticias nos dificulte reencontrarlo.

Por este motivo, se impone hablar de la reciente aparición de Eco de un ave que estalla, de Heber Quijano (Diablura Ediciones, 2020). La obra se divide en ocho apartados que recogen un hilo de aforismos iniciado en 2012 por el escritor mexiquense en su cuenta de Twitter @heberquijano. El libro rescata de los traslapes de los tuits y retuits una colección de sentencias con temas y estructuras transversales que valen ser catalogados de intergenéricos. Los tópicos se suceden y encabalgan mediante una hebra discursiva que nos arrastra por paisajes urbanos, realidades incómodas, universos liliputienses, fondos marinos y futuros distópicos. El filamento se tensa y perfora a quemarropa como un caudal violento de balas que pronto se transforma en la larva fratricida que carcome y corrompe nuestras sociedades: la violencia gratuita, la violencia política, la de la desigualdad, como se pone de relieve en los siguientes fragmentos:

De niño, granizaba súbitamente por mi casa. Eso decía papá. Ahora sé que eran balas perdidas. La tempestad no ha amainado

Tenía 9 años, cruzaba una calle cualquiera. Me dejó sin mano. De noche siento comezón y debo cortarle las uñas

Aun dormido, al veterano de guerra le tintinean casquillos de balas perdidas en el laberinto del tímpano. Sin estallar (14). ${ }^{1}$

1 Todas las citas pertenecientes a Eco de un ave de estalla, corresponden a Quijano (2020), por lo cual solo se anota el número de página. 
Las imágenes desplegadas en el apartado "Bala perdida" retumban como un poderoso tiroteo de 52 aforismos cuya secuencia libera en la mente del lector una calamitosa madeleine de Proust sobre aquellas historias compartidas que componen el tejido social de México.

Mediante un encadenamiento concienzudo sobre la letalidad de lo minúsculo, Heber Quijano se suma a una tradición literaria que retrata la parafernalia mortífera de la bala como leitmotiv irresoluto desde la Revolución. Sus cavilaciones, sin embargo, decantan y se entretienen en las virtudes de lo ínfimo, cuya letalidad no escapa a la belleza y nos traslada diestramente hacia universos imaginativos donde cada aforismo se vuelve una especie de gragea en la que vale la pena dilatarse:

Entre los riscos y corales, casi fantasmal, anda una mano asimétrica. Parece una siniestra amputación

Después del colapso de los mares, hubo cazadores de esqueletos de estrellas de mar tan preciado como el marfil y la seda

Los cardúmenes de estrellas de mar también forman constelaciones. Secretamente dirigen los destinos de los pescadores (53)

Las evocadoras imágenes de los aforismos a lo largo de "La caracola" y "Estrella de mar" abren puertas a escenarios fantásticos, se erigen como piedras angulares sobre las cuales cimentar otras historias y mundos posibles. Su voz compone jitanjáforas, juega a crear nuevas vías para dichos tópicos poéticos que lo acercan a la literatura de vanguardia y hacen pensar en el espíritu de los poetas de la generación del 27.

Heber Quijano es conocido en el medio literario particularmente por sus poemarios Derroteros del alba (variaciones sobre el deseo) (Premio Internacional de Poesía Gilberto Owen Estrada, UAEM, 2006), Cuerda floja (Consejo Editorial de la Administración Pública Estatal, 2010), Esfinges de hojarasca (Diablura Ediciones, 2015), y diversos folios de poesía en esta revista (La Colmena, núms. 55, 76, 77 y 100). Al igual que a muchos escritores y poetas 
contemporáneos, puede seguírsele en diversas redes sociales y en su blog. ${ }^{2}$ Su trabajo es tan variado como las plataformas a las que abona, de tal manera que no es de extrañar que, como numerosos autores hoy en día, haya decidido nutrir el diálogo en torno a la llamada tuiteratura sin más ánimo que el desafío que impone el ejercicio de escribir contenido de una extensión máxima de 140 caracteres, como exigía la plataforma antes de 2017.

Nos maravillamos frente a formas literarias añejas, cuya estructura se erige de repente novedosa y propia de nuestro tiempo al trasladarse de la hoja de papel al feed. Su presencia en la plataforma digital Twitter la dota de tal soplo de actualidad que nos impulsa a apropiárnosla y compartirla. De hecho, son muchas las cuentas que rescatan máximas o versos. Incluso nos han recordado que la práctica de condensar contenidos no es reciente y, sobre todo, es multiforme. Pienso en @novelsin3lines, cuenta que tuitea los breves periodísticos de Félix Fenéon, crítico de arte francés que en 1906 colaboró en la sección "Nouvelles en trois lignes", del periódico Le Matin, donde se publicaban noticias de 135 caracteres, con interés particular por lo trágico y los fait-divers. Fenéon se vale de variados recursos retóricos que elevan la nota a un nivel poético, misma línea que explora Quijano en algunos apartados del libro, aunque no solamente, puesto que la serie de aforismos propuestos embelesa en particular por el cabal equilibrio de temas y tonos. Requiere destreza ser capaz de mantener tensa la cuerda por la que el lector avanza como funámbulo, a veces con vértigo, otras, ingrávido.

Si Eco de un ave que estalla, en un movimiento inverso, se ha vertido del feed al papel, es precisamente porque un formato tangible nos permite rescatar la poesía y separarla del hontanar irrefrenable de palabrería de la web. Este impulso por conservarla se rastrea en la primera tentativa de edición de uno de sus apartados, allá por 2013, en el Pliego de Poesía de La Colmena, núm. 77, Fragmentaria. La caracola. Es la universalidad global de la obra lo que nos prende de ella y nos cosquillea en la nuca como un antiguo déjà vu.

Había comenzado estas líneas evocando el olvido y la memoria, movimiento reflejo de selección y conservación. Andar desmemoriados sería, entonces, una de las condicionantes más importantes para la recepción exitosa o fallida de determinada forma literaria, de ahí el triunfo del aforismo contemporáneo o nanoblogueo y del libro que nos atañe. A lo anterior, cabría agregar nuestra predilección consustancial como hispanohablantes por las sentencias breves de

2 https:/heberquijano.com/ 
contenidos profundos. No por nada continuamos guiándonos por las máximas de Gracián: "más valen quintaesencias que fárragos", por citar una sola.

Propio de la tradición culta y popular, la madeja de las formulaciones sintéticas se extiende desde la Grecia antigua y viaja por distintas culturas. En el mundo occidental resurgió en las vanguardias, y a nivel global nos acompaña con los servicios de microblogueo. Eco de un ave que estalla rescata del olvido y pone la mirilla sobre los espectros de lo cotidiano, pronuncia los nombres que yacen marginados y que se esconden detrás de los objetos del día a día. Quijano se perfila como un observador a lo Ginsberg, que obliga a detener el ojo en lo que voluntaria o involuntariamente habíamos olvidado o queríamos olvidar.

Lizarlett Flores Díaz. Profesora certificada de Español como Lengua Extranjera (CAPES-CAFEP) y Maestra en Estudios Hispánicos e Hispanoamericanos por la Universidad Bordeaux Montaigne (Burdeos, Francia), donde actualmente se desempeña como profesora asociada de traducción. 